ISSN 0258-7122 (Print), 2408-8293 (Online)

Bangladesh J. Agril. Res. 42(4): 609-620, December 2017

\title{
MANAGEMENT OF CAULIFLOWER SEEDLING DISEASE (Sclerotium rolfsii) IN SEEDBED WITH DIFFERENT SUBSTRATE BASED Trichoderma harzianum BIO-FUNGICIDES
}

\author{
M. I. FARUK ${ }^{1}$ AND M. L. RAHMAN ${ }^{2}$
}

\begin{abstract}
Efficacy of rice bran, wheat bran, grass pea bran and their combinations with or without mustard oilcake (MOC) were tested as substrate of Trichoderma harzianum based bio-fungicides for the management of foot and root rot disease of cauliflower caused by Sclerotium rolfsii in the seedbed during three consecutive growing seasons from 2011 through 2014 in the net house of Bangladesh Agricultural Research Institute, Gazipur. The seedbed soil was inoculated with pathogen $S$. rolfsii colonized on barley grain before treatment with $T$. harzianum based bio-fungicides. The results of three years trial revealed that $T$. harzianum based bio-fungicides effectively reduced pre-emergence and post-emergence mortality of cauliflower seedling in seedbed. Besides, vegetative growth of cauliflower seedlings viz. shoot length, shoot weight, root length and root weight were enhanced significantly by different substrates based $T$. harzianum bio-fungicides in $S$. rolfsii sick seedbed. The substrates rice bran, wheat bran, grass pea bran and their combination with mustard oilcake (MOC) were equally suitable for effective formulation of $T$. harzianum bio-fungicides against foot and root rot disease of cauliflower in seedbed.
\end{abstract}

Keyword: Cauliflower, seedling disease, Sclerotium rolfsii, bio-fungicide, Trichoderma harzianum.

\section{Introduction}

Cauliflower (Brassica oleracea var. botrytis) is cultivated in about 13 thousand hectares of land with a production of about 166 thousand tons in Bangladesh (BBS, 2013). The productivity of cauliflower in Bangladesh is low as compared to that of other countries (FAOSTAT, 2012). It is estimated that about 10\% crops are lost worldwide annually due to plant diseases which lead to considerable economic discrepancy to the farmers of underdeveloped countries (Strange and Scott, 2005). Germination failure and seedling mortality caused by the soil borne pathogens are the major constraints of cauliflower in seed bed. Among the soil borne pathogens, S. rolfsii is one of the major one for seedling production of vegetable crops including cauliflower especially in seedbed (Najar et al., 2011). The soil borne pathogen $S$. rolfsii produces a unique and specialized structure called sclerotia which can survive in soil under adverse environmental conditions (Mondal et al., 1996). So, it is very difficult to control through conventional

${ }^{1}$ Senior Scientific Officer, Plant Pathology Division, Bangladesh Agricultural Research Institute (BARI), Gazipur-1017, ${ }^{2}$ Director (Research), BARI, Gazipur-1017, Bangladesh. 
methods such as application of fungicides, cultural methods, etc. Resistant variety of cauliflower has not yet been developed against $S$. rolfsii in Bangladesh. Besides, chemical fungicides are expensive and also hazardous to health and environment (Brown and Hendrix, 1980; Punja et. al., 1982). Biological control methods, on the other hand can be considered as cost-effective, sustainable and environment-friendly option for soil borne disease management (Kulkarni et al., 2007; Anand and Reddy, 2009). The biological agent Trichoderma harzianum has reported by many researchers describing the scenario and mechanisms of controlling soil-borne plant pathogens (Morsy et al., 2009; Sabalpara et al., 2009; Benítez et al., 2004; Harman et al., 2004). The fungus Trichoderma harzianum has a stimulatory effect on plant growth (Naseby et al., 2000) as well as having potentiality as antagonists to control Sclerotium, Phytophthora, Pythium, Sclerotinia, Botrytis, Rhizoctonia and Fusarium (Benítez et al., 2004; Roy et al., 1989). The native bio-control agents usually perpetuate in low population density in most of the agricultural soil, so up-scaling of their density to a higher stability level in soil through artificial inoculation is necessary for effective management of soil borne pathogens $S$. rolfsii. The major limitation is the lack of appropriate mass culturing techniques and inadequate information on the suitable substrate materials of T. harzianum (Harman et al., 1991). Several research reported various substrates for $T$. harzianum culture viz. wheat bran, rice bran, maize bran, sawdust (Das et al., 1997); rice straw, chickpea bran, grass pea bran, rice course powder, black gram bran (Shamsuzzaman et al., 2003); cow dung, poultry manure, ground nut shell, black ash, coir waste, spent straw from mushroom bed, talc, vermiculite (Rettinassababady and Ramadoss, 2000); and jaggery, groundnut cake, neem cake, niger cake, pongamia (Shamarao et al., 1998). Most of these substrates are available in Bangladesh but their potentialities to mass culture of $T$. harzianum is yet to be determined in the country. Therefore, the present study was undertaken to find out the suitable and cost-effective substrates for mass culturing of $T$. harzianum to be used as effective bio-fungicides against $S$. rolfsii causing seedling disease of cauliflower in seedbed.

\section{Materials and Methods}

Three organic substrates viz. rice bran, wheat bran, grasspea bran and their combinations were mixed with or without mustard oilcake (MOC) for mass multiplication of $T$. harzianum against seedling disease ( $S$. rolfsii) of cauliflower in seedbed of Plant Pathology Division, Bangladesh Agricultural Research Institute (BARI), Gazipur during three consecutive seasons from 2011 to 2014.

\section{a) Seedbed inoculation with $S$. rolfsii}

Isolates of $S$. rolfsii was grown on potato dextrose agar (PDA) medium and used as inoculum. Two hundred gram of barley grains were taken in $500 \mathrm{ml}$ 
Erlenmeyer flask and sterilized the grains in an autoclave at $121{ }^{\circ} \mathrm{C}$ for 15 minutes. The sterilized barley grains were inoculated with mycelial blocks of $S$. rolfsii grown on PDA and allowed to grow. The completely colonized barley grains were air dried and incorporated with the seedbed soils@100 g/ $\mathrm{m}^{2}$ soil. The pathogen was allowed to establish in seedbed soil for 10 days with proper soil moisture.

\section{b) Substrates used for T. harzianum multiplication}

Seventy two isolates of $T$. harzianum were obtained from different location of Bangladesh and their efficacy was tested against different soil borne pathogens including $S$. rolfsii in the laboratory using dual culture technique. Among them T. harzianum TM7 isolate was found most vigorous to suppress $S$. rolfsii. Therefore, a pure culture of $T$. harzianum (TM7) was grown in potato dextrose agar (PDA) medium and was used as source of bio-fungicide. The substrates rice bran, wheat bran, grass pea bran and their combination with or without mustard oilcake (MOC) were used for multiplication of $T$. harzianu.

\section{c) Bio-fungicide application}

The experiment was laid out in the $S$. rolfsii sick seedbed under net-house condition using completely randomized design with four replications where the treatment (substrates) combinations were $T_{1}=$ Rice bran, $T_{2}=$ Wheat bran, $T_{3}=$ Grasspea bran, $\mathrm{T}_{4}=$ Rice bran + Wheat bran $(1: 1), \mathrm{T}_{5}=$ Rice bran + Grasspea bran (1:1), $\mathrm{T}_{6}=$ Rice bran + Mustard oilcake (1:1), $\mathrm{T}_{7}=$ Rice bran + Wheat bran + Mustard oilcake (1:1:1), $\mathrm{T}_{8}=$ Rice bran + Grasspea bran + Mustard oilcake (1:1:1), $\mathrm{T}_{9}=$ Wheat bran + Grasspea bran + Mustard oilcake $(1: 1: 1), \mathrm{T}_{10}=$ Rice bran + Wheat bran + Grass pea bran + Mustard oilcake (1:1:1:1), $\mathrm{T}_{11}=$ Seed treatment with Provax and $\mathrm{T}_{12}=$ Control. According to the treatment combinations $600 \mathrm{~g}$ of individual or mixed substrate materials were taken separately in $1000 \mathrm{ml}$ Erlenmeyer flask and were sterilized. The sterilized substrate was inoculated individually with $5 \mathrm{~mm}$ diameter mycelia disc of fiveday old T. harzianum culture grown on PDA and then incubated at room temperature $\left(25 \pm 2{ }^{\circ} \mathrm{C}\right)$ for 15 days until complete colonization. After incubation the colonized substrates were removed from the flasks, air dried and finally preserved in refrigerator at $10{ }^{\circ} \mathrm{C}$. The inoculum of $T$. harzianum, colonized on different substrates, were incorporated to the previously $S$. rolfsii inoculated seedbed soils@100 g/m² (Faruk et. al., 2014) soil and kept for 7 days maintaining proper soil moisture to establish $T$. harzianum in the soils. The control bed did not receive any colonized substrate of $T$. harzianum except the inoculum of $S$. rolfsii. 


\section{d) Raising of Seedling}

After 7 days of $T$. harzianum bio-fungicide incorporation in the soil, the seeds of cauliflower variety Rupa were sown in the seedbed @ 200 seeds (split in four which consider as a replication) per treatment. The initial germination of the seeds was $99 \%$ in blotter test. The percent emergence of the seedling was calculated on the basis of initial germination status of the seeds. The experiment was laid out in completely randomized design (CRD) with four replications. Proper weeding, irrigation and intercultural operations were done. Data were collected on seedling emergence after 15 days of seed sowing. Similarly seedling mortality was recorded at an interval of 7 days starting from seedling emergence and it was continued up to 35 days of seedling age. The height and weight of shoot and also length and weight of root of cauliflower seedlings were recorded at 35 days of seedling age. The percent data were converted into arcsine transformation values before statistical analysis. Data were analyzed statistically by using the MSTATC program. The treatment effects were compared by applying the least significant different (LSD) test at $\mathrm{P}=0.05$ level.

\section{Results and Discussion}

\section{a) Emergence and pre-emergence mortality of cauliflower seedling}

Emergence of cauliflower seedling in the $S$. rolfsii was enhanced due to application of different substrate material based $T$. harzianum bio-fungicide in consecutive three years. The seedling emergence varied from 58.33-67\% among the bio-fungicide treated beds whereas untreated control bed gave comparatively low emergence $(53 \%)$ in $1^{\text {st }}$ year trial (Table 1). Similarly, the bio-fungicides gave higher seedling emergence in $2^{\text {nd }}$ year $(59-65.33 \%)$ and $3^{\text {rd }}$ year $(86-97 \%)$ while control seed beds showed $49.33 \%$ and $79 \%$ seedling emergence, respectively. The $T$. harzianum bio-fungicide treated seed beds showed lower pre-emergence mortality of cauliflower seedlings as compared to untreated control beds in all the years (Table 1).

The pre-emergence mortality was lower among the bio-fungicide treated seedbeds during $1^{\text {st }}$ year $(33-41.67 \%), 2^{\text {nd }}$ year $(34.67-41 \%)$ and $3^{\text {rd }}$ year $(3-14 \%)$ although in control bed it was $47,50.67$, and $21 \%$, respectively. The results indicated that the effect of single and mixed substrate based T. harzianum biofungicides were almost similar among themselves in respect of emergence as well as pre-emergence mortality of cauliflower seedling in $S$. rolfsii sick seedbed. Thus it is revealed from the results that the emergence of cauliflower seedlings was sharply increased by the $T$. harzianum bio-fungicides and better substrates were rice, grasspea, wheat and rice + wheat, rice + grasspea for preparing biofungicide (Table 1). 
Table 1. Effect of different substrate based $T$. harzianum bio-fungicides on the emergence and mortality of cauliflower seedling in Sclerotium rolfsii inoculated seedbed

\begin{tabular}{|c|c|c|c|c|c|c|}
\hline \multirow[t]{2}{*}{$\begin{array}{c}\text { Name of substrates based } \\
\text { bio-fungicide }\end{array}$} & \multicolumn{3}{|c|}{$\begin{array}{l}\text { Emergence }(\%) \text { of cauliflower } \\
\text { seedling in seedbed }\end{array}$} & \multicolumn{3}{|c|}{$\begin{array}{c}\text { Pre-emergence mortality (\%) } \\
\text { of cauliflower seedling in } \\
\text { seedbed }\end{array}$} \\
\hline & $1^{\text {st }}$ year & $2^{\text {nd }}$ year & $3^{\text {rd }}$ year & $1^{\text {st }}$ year & $2^{\text {nd }}$ year & $3^{\text {rd }}$ year \\
\hline Rice bran & $\begin{array}{l}66.33 \mathrm{a} \\
(54.53)\end{array}$ & $\begin{array}{l}59.67 \mathrm{a} \\
(50.58)\end{array}$ & $\begin{array}{l}86.00 \mathrm{~d} \\
(68.10)\end{array}$ & 33.67 & 40.33 & 14.00 \\
\hline Wheat bran & $\begin{array}{c}62.67 \mathrm{ab} \\
(52.40)\end{array}$ & $\begin{array}{l}59.67 \mathrm{a} \\
(50.59)\end{array}$ & $\begin{array}{l}97.00 \mathrm{a} \\
(80.46)\end{array}$ & 37.67 & 40.33 & 03.00 \\
\hline Grasspea bran & $\begin{array}{c}64.33 \mathrm{ab} \\
(53.33)\end{array}$ & $\begin{array}{l}61.33 \mathrm{a} \\
(51.55)\end{array}$ & $\begin{array}{l}89.00 \mathrm{~cd} \\
(70.74)\end{array}$ & 35.67 & 38.67 & 11.00 \\
\hline Rice bran + Wheat bran & $\begin{array}{c}61.00 \mathrm{ab} \\
(51.35)\end{array}$ & $\begin{array}{l}61.33 \mathrm{a} \\
(51.58)\end{array}$ & $\begin{array}{l}94.00 \mathrm{~b} \\
(76.42)\end{array}$ & 39.00 & 38.67 & 06.00 \\
\hline $\begin{array}{l}\text { Rice bran + Grass pea } \\
\text { bran }\end{array}$ & $\begin{array}{l}67.00 \mathrm{a} \\
(54.94)\end{array}$ & $\begin{array}{l}60.67 \mathrm{a} \\
(51.16)\end{array}$ & $\begin{array}{l}89.00 \mathrm{~cd} \\
(70.68)\end{array}$ & 33.00 & 39.67 & 11.00 \\
\hline $\begin{array}{l}\text { Rice bran }+ \text { Mustard } \\
\text { oilcake }\end{array}$ & $\begin{array}{c}60.33 \mathrm{ab} \\
(50.96)\end{array}$ & $\begin{array}{l}64.00 \mathrm{a} \\
(53.20)\end{array}$ & $\begin{array}{l}91.00 \mathrm{bc} \\
(72.70)\end{array}$ & 39.67 & 36.00 & 09.00 \\
\hline $\begin{array}{l}\text { Rice bran }+ \text { Wheat bran }+ \\
\text { MOC }\end{array}$ & $\begin{array}{l}58.33 \mathrm{bc} \\
(49.80)\end{array}$ & $\begin{array}{l}65.33 \mathrm{a} \\
(54.04)\end{array}$ & $\begin{array}{l}93.00 \mathrm{bc} \\
(74.68)\end{array}$ & 41.67 & 34.67 & 07.00 \\
\hline $\begin{array}{l}\text { Rice bran }+ \text { Grasspea } \\
\text { bran }+ \text { MOC }\end{array}$ & $\begin{array}{c}61.00 \mathrm{ab} \\
(51.34)\end{array}$ & $\begin{array}{l}61.00 \mathrm{a} \\
(51.37)\end{array}$ & $\begin{array}{l}93.00 \mathrm{bc} \\
(74.76)\end{array}$ & 39.00 & 39.00 & 07.00 \\
\hline $\begin{array}{l}\text { Wheat bran + Grass pea } \\
\text { bran + MOC }\end{array}$ & $\begin{array}{l}60.67 \mathrm{ab} \\
(51.16)\end{array}$ & $\begin{array}{l}59.00 \mathrm{a} \\
(50.19)\end{array}$ & $\begin{array}{l}97.00 \mathrm{a} \\
(80.46)\end{array}$ & 39.33 & 41.00 & 03.00 \\
\hline $\begin{array}{l}\text { Wheat bran + Grass pea } \\
\text { bran+ Rice bran + MOC }\end{array}$ & $\begin{array}{c}64.67 \mathrm{ab} \\
(53.53)\end{array}$ & $\begin{array}{l}60.33 \mathrm{a} \\
(51.04)\end{array}$ & $\begin{array}{l}91.00 \mathrm{bc} \\
(72.83)\end{array}$ & 35.33 & 39.67 & 09.00 \\
\hline $\begin{array}{l}\text { Seed treatment with } \\
\text { Provax }\end{array}$ & $\begin{array}{l}64.33 \mathrm{ab} \\
(53.32)\end{array}$ & $\begin{array}{l}61.00 \mathrm{a} \\
(51.37)\end{array}$ & $\begin{array}{l}90.00 \mathrm{~cd} \\
(71.70)\end{array}$ & 35.67 & 39.00 & 10.00 \\
\hline Control & $\begin{array}{l}53.00 \mathrm{c} \\
(46.72)\end{array}$ & $\begin{array}{l}49.33 \mathrm{~b} \\
(44.62)\end{array}$ & $\begin{array}{l}79.00 \mathrm{e} \\
(62.83)\end{array}$ & 47.00 & 50.67 & 21.00 \\
\hline $\operatorname{LSD}(\mathrm{P}=0.05)$ & 6.56 & 4.788 & 3.712 & - & - & - \\
\hline
\end{tabular}

Values in a column with same letter did not differ significantly $(\mathrm{P}=0.05)$ by LSD; values within the parenthesis is the Arcsin Transformed value.

\section{b) Post-emergence mortality of cauliflower seedling}

Post-emergence mortality of cauliflower seedling in $S$. rolfsii sick seedbed was significantly reduced each year by different substrate based $T$. harzianum biofungicides and Provax as compared to the untreated control. The seedling mortality in $1^{\text {st }}$ year trial was $21 \%$ in the untreated control while it ranged from 7 to $9.33 \%$ in rest treatments (Table 2). Thus the seedling mortality was reduced ranging from 55.57 to $66.67 \%$ over control due to bio-fungicide treatment. In the $2^{\text {nd }}$ year trial, 11.33 to $14.33 \%$ seedling mortality was observed in the biofungicides and Provax treated seedbeds where control bed showed $38.33 \%$ mortality and the reduction of seedling mortality ranged from 62.61 to $70.44 \%$. 
The seedling mortality in the bio-fungicides treated seedbeds and untreated control bed in the $3^{\text {rd }}$ year trial were also showed similar trend of results. The effect of Provax was almost similar to bio-fungicides in reducing seedling mortality in each year. The individual and mixed substrate material based $T$. harzianum bio-fungicides were equally effective against the post-emergence mortality of cauliflower seedling in S. rolfsii sick seedbeds. The T. harzianum destroyed the pathogenic fungi through increasing the expression of cell wall degrading enzymes, mostly chitinases, glucanases and proteases (Harman et al., 2004). Most of the Trichoderma strains produce volatile and onvolatile toxic metabolites that obstruct colonization by antagonistic microorganisms. Some of these metabolites were harzianic acid, alamethicins, tricholin, peptaibols, 6penthyl-alpha-pyrone, massoilactone, viridin, gliovirin, glisoprenins, and heptelidic acid (Vey et al., 2001).

Table 2. Reduction of cauliflower seedling mortality by different substrate based $T$. harzianum bio-fungicides in Sclerotium rolfsii inoculated seedbed

\begin{tabular}{|c|c|c|c|c|c|c|}
\hline \multirow[t]{2}{*}{$\begin{array}{c}\text { Name of substrates based } \\
\text { bio-fungicide }\end{array}$} & \multicolumn{3}{|c|}{$\begin{array}{c}\text { Post-emergence mortality (\%) } \\
\text { of cauliflower seedling }\end{array}$} & \multicolumn{3}{|c|}{$\begin{array}{l}\text { Reduction of cauliflower } \\
\text { seedling mortality }(\%) \text { over } \\
\text { control }\end{array}$} \\
\hline & $1^{\text {st }}$ year & $2^{\text {nd }}$ year & $3^{\text {rd }}$ year & $1^{\text {st }}$ year & $2^{\text {nd }}$ year & $3^{\text {rd }}$ year \\
\hline Rice bran & $\begin{array}{l}8.67 \mathrm{bc} \\
(17.13)\end{array}$ & $\begin{array}{l}11.33 \mathrm{~b} \\
(19.64)\end{array}$ & $\begin{array}{l}9.33 \mathrm{~b} \\
(17.78)\end{array}$ & 58.71 & 70.44 & 67.07 \\
\hline Wheat bran & $\begin{array}{l}9.00 \mathrm{bc} \\
(17.49)\end{array}$ & $\begin{array}{l}12.00 \mathrm{~b} \\
(21.09)\end{array}$ & $\begin{array}{l}10.00 \mathrm{~b} \\
(18.38)\end{array}$ & 57.14 & 68.69 & 64.70 \\
\hline Grasspea bran & $\begin{array}{l}8.67 \mathrm{bc} \\
(17.18)\end{array}$ & $\begin{array}{l}13.00 \mathrm{~b} \\
(20.23)\end{array}$ & $\begin{array}{l}10.33 \mathrm{~b} \\
(18.74)\end{array}$ & 58.71 & 66.08 & 63.54 \\
\hline Rice bran + Wheat bran & $\begin{array}{l}9.33 \mathrm{~b} \\
(17.81)\end{array}$ & $\begin{array}{l}12.67 \mathrm{~b} \\
(20.81)\end{array}$ & $\begin{array}{l}8.67 \mathrm{~b} \\
(17.10)\end{array}$ & 55.57 & 66.94 & 69.39 \\
\hline Rice bran + Grasspea bran & $\begin{array}{l}8.00 \mathrm{bc} \\
(16.43)\end{array}$ & $\begin{array}{l}13.67 \mathrm{~b} \\
(21.68)\end{array}$ & $\begin{array}{l}10.67 \mathrm{~b} \\
(19.04)\end{array}$ & 61.90 & 64.34 & 62.34 \\
\hline $\begin{array}{l}\text { Rice bran }+ \text { Mustard } \\
\text { oilcake }\end{array}$ & $\begin{array}{l}7.67 \mathrm{bc} \\
(15.72)\end{array}$ & $\begin{array}{l}11.33 \mathrm{~b} \\
(19.64)\end{array}$ & $\begin{array}{c}9.33 \mathrm{~b} \\
(17.63)\end{array}$ & 63.48 & 70.44 & 67.07 \\
\hline $\begin{array}{l}\text { Rice bran }+ \text { Wheat bran }+ \\
\text { MOC }\end{array}$ & $\begin{array}{l}8.67 \mathrm{bc} \\
(17.17)\end{array}$ & $\begin{array}{l}12.33 \mathrm{~b} \\
(20.56)\end{array}$ & $\begin{array}{l}11.33 \mathrm{~b} \\
(19.67)\end{array}$ & 58.71 & 67.83 & 60.00 \\
\hline $\begin{array}{l}\text { Rice bran +Grasspea bran } \\
+ \text { MOC }\end{array}$ & $\begin{array}{l}8.67 \mathrm{bc} \\
(17.19)\end{array}$ & $\begin{array}{l}14.00 \mathrm{~b} \\
(21.84)\end{array}$ & $\begin{array}{l}9.67 \mathrm{~b} \\
(18.05)\end{array}$ & 58.71 & 63.47 & 65.86 \\
\hline $\begin{array}{l}\text { Wheat bran + Grasspea } \\
\text { bran }+ \text { MOC }\end{array}$ & $\begin{array}{l}8.33 \mathrm{bc} \\
(16.79)\end{array}$ & $\begin{array}{l}14.33 \mathrm{~b} \\
(22.21)\end{array}$ & $\begin{array}{l}10.33 \mathrm{~b} \\
(18.74)\end{array}$ & 60.33 & 62.61 & 63.54 \\
\hline $\begin{array}{l}\text { Wheat bran + Grasspea } \\
\text { bran+ Rice bran + MOC }\end{array}$ & $\begin{array}{l}7.00 \mathrm{c} \\
(15.35)\end{array}$ & $\begin{array}{l}12.00 \mathrm{~b} \\
(20.26)\end{array}$ & $\begin{array}{l}9.33 \mathrm{~b} \\
(17.75)\end{array}$ & 66.67 & 68.69 & 67.07 \\
\hline Seed treatment with Provax & $\begin{array}{l}7.67 \mathrm{bc} \\
(16.12)\end{array}$ & $\begin{array}{l}12.67 \mathrm{~b} \\
(20.82)\end{array}$ & $\begin{array}{l}10.67 \mathrm{~b} \\
(19.03)\end{array}$ & 63.48 & 66.94 & 62.34 \\
\hline Control & $\begin{array}{l}21.00 \mathrm{a} \\
(26.57)\end{array}$ & $\begin{array}{l}38.33 \mathrm{a} \\
(38.24)\end{array}$ & $\begin{array}{l}28.33 \mathrm{a} \\
(32.16)\end{array}$ & - & - & - \\
\hline $\operatorname{LSD}(\mathrm{P}=0.05)$ & 1.88 & 2.621 & 2.515 & & & \\
\hline
\end{tabular}

Values in a column with same letter did not differ significantly $(\mathrm{P}=0.05)$ by LSD; values within the parenthesis is the Arcsin Transformed value. 


\section{c) Shoot growth of cauliflower seedling}

The shoot growth of cauliflower seedling was significantly accelerated by the application of various substrate based T. harzianum bio-fungicides and Provax in $S$. rolfsii sick seedbed every year. In the $1^{\text {st }}$ year trial, the shoot length of cauliflower seedling varied from 27.53 to $30.17 \mathrm{~cm}$ among the $T$. harzianum biofungicide treated seedbeds whereas it was $22 \mathrm{~cm}$ in the untreated control (Table $3)$. Taller seedlings $(17.20-22.13 \mathrm{~cm})$ of cauliflower were found in the biofungicides treated seedbed and shorter seedlings $(15.57 \mathrm{~cm})$ were in the control seedbed during $2^{\text {nd }}$ year trial. The shoot length ranged from 18.67 to $22.33 \mathrm{~cm}$ in the bio-fungicides treated seedbeds in the $3^{\text {rd }}$ trial and $13.00 \mathrm{~cm}$ in the control seedbed.

Table 3. Effect of different substrate based $T$. harzianum bio-fungicides on the shoot growth of cauliflower seedling in Sclerotium rolfsii inoculated seedbed

\begin{tabular}{|c|c|c|c|c|c|c|}
\hline \multirow[t]{2}{*}{$\begin{array}{l}\text { Name of substrates } \\
\text { based bio-fungicides }\end{array}$} & \multicolumn{3}{|c|}{$\begin{array}{l}\text { Shoot length of cauliflower } \\
\text { seedlings in three years }(\mathrm{cm})\end{array}$} & \multicolumn{3}{|c|}{$\begin{array}{c}\text { Shoot weight of cauliflower } \\
\text { seedlings in three years } \\
\text { (g/plant) }\end{array}$} \\
\hline & $1^{\text {st }}$ year & $2^{\text {nd }}$ year & $3^{\text {rd }}$ year & $1^{\text {st }}$ year & $2^{\text {nd }}$ year & $3^{\text {rd }}$ year \\
\hline Rice bran & $27.53 \mathrm{ab}$ & $18.93 \mathrm{bc}$ & $20.67 \mathrm{ab}$ & $6.07 \mathrm{a}$ & $6.73 \mathrm{~b}$ & $12.20 \mathrm{bc}$ \\
\hline Wheat bran & $28.47 \mathrm{ab}$ & $17.20 \mathrm{bc}$ & $18.67 \mathrm{bc}$ & $5.87 \mathrm{ab}$ & $6.99 \mathrm{~b}$ & $11.80 \mathrm{bc}$ \\
\hline Grasspea bran & $28.40 \mathrm{ab}$ & $17.27 \mathrm{bc}$ & $19.47 \mathrm{~b}$ & $6.20 \mathrm{a}$ & $6.57 \mathrm{~b}$ & $11.93 \mathrm{bc}$ \\
\hline Rice bran + Wheat bran & $29.30 \mathrm{a}$ & $20.93 \mathrm{ab}$ & $19.93 \mathrm{ab}$ & $6.27 \mathrm{a}$ & $6.96 \mathrm{~b}$ & $12.37 \mathrm{~b}$ \\
\hline $\begin{array}{l}\text { Rice bran + Grasspea } \\
\text { bran }\end{array}$ & $30.17 \mathrm{a}$ & $21.07 \mathrm{ab}$ & $21.40 \mathrm{ab}$ & $6.13 \mathrm{a}$ & $6.57 \mathrm{~b}$ & $13.63 \mathrm{a}$ \\
\hline $\begin{array}{l}\text { Rice bran }+ \text { Mustard } \\
\text { oilcake }\end{array}$ & $27.80 \mathrm{ab}$ & $22.13 \mathrm{a}$ & $19.70 \mathrm{ab}$ & $6.10 \mathrm{a}$ & $8.48 \mathrm{a}$ & $11.60 \mathrm{bc}$ \\
\hline $\begin{array}{l}\text { Rice bran + Wheat bran } \\
+ \text { MOC }\end{array}$ & $27.53 \mathrm{ab}$ & $21.47 \mathrm{ab}$ & $19.87 \mathrm{ab}$ & $5.73 \mathrm{ab}$ & $8.47 \mathrm{a}$ & $11.17 \mathrm{c}$ \\
\hline $\begin{array}{l}\text { Rice bran+ Grasspea } \\
\text { bran +MOC }\end{array}$ & $27.80 \mathrm{ab}$ & $21.47 \mathrm{ab}$ & $20.23 \mathrm{ab}$ & $5.80 \mathrm{ab}$ & $8.38 \mathrm{a}$ & $12.00 \mathrm{bc}$ \\
\hline $\begin{array}{l}\text { Wheat bran + Grasspea } \\
\text { bran + MOC }\end{array}$ & $27.83 \mathrm{ab}$ & $21.77 \mathrm{ab}$ & $22.33 \mathrm{a}$ & $5.77 \mathrm{ab}$ & $8.83 \mathrm{a}$ & $13.70 \mathrm{a}$ \\
\hline $\begin{array}{l}\text { Wheat bran + Grasspea } \\
\text { bran+ Rice bran + MOC }\end{array}$ & $27.87 \mathrm{ab}$ & $21.97 \mathrm{ab}$ & $20.33 \mathrm{ab}$ & $6.07 \mathrm{a}$ & $8.70 \mathrm{a}$ & $11.20 \mathrm{c}$ \\
\hline $\begin{array}{l}\text { Seed treatment with } \\
\text { Provax }\end{array}$ & $25.80 \mathrm{~b}$ & $16.76 \mathrm{c}$ & $16.93 \mathrm{c}$ & $5.30 \mathrm{~b}$ & $4.43 \mathrm{c}$ & $9.77 \mathrm{~d}$ \\
\hline Control & $22.00 \mathrm{c}$ & $15.57 \mathrm{c}$ & $13.00 \mathrm{~d}$ & $3.93 \mathrm{c}$ & $3.47 \mathrm{~d}$ & $8.57 \mathrm{e}$ \\
\hline $\operatorname{LSD}(\mathrm{P}=0.05)$ & 2.335 & 2.543 & 2.394 & 0.546 & 0.566 & 0.92 \\
\hline
\end{tabular}

Values in a column with same letter did not differ significantly $(\mathrm{p}=0.05)$ by LSD.

The shoot weight of cauliflower seedling was significantly increased by the $T$. harzianum bio-fungicides over untreated control. In the $1^{\text {st }}$ year trial, the shoot weight was 5.73-6.27 $\mathrm{g}$ in T. harzianum bio-fungicide treated while it was $3.93 \mathrm{~g}$ in control (Table 3). The bio-fungicide treated beds gave shoot weight of 6.57 to 
$8.83 \mathrm{~g}$ in the $2^{\text {nd }}$ year and 11.20 to $13.70 \mathrm{~g}$ in the $3^{\text {rd }}$ year trial while in untreated seedling it gave 3.47 and $8.57 \mathrm{~g}$ shoot weights, respectively. The lower shoot weight was noticed in the Provax treated beds as compared to bio-fungicide treated seedbeds in each year. The results indicated that the substrates rice, wheat + grasspea + mustard oilcake, and wheat + rice + grasspea + mustard oilcake based $T$. harzianum bio-fungicides were better in respect of shoot growth of cauliflower seedling in addition to seedling disease reduction caused by $S$. rolfsii under seed bed conditions. The T. harzianum was reported to play a positive role in seed germination, plant growth, rapid flowering and weight of plants (Chang et al., 1986).

\section{d) Root growth of cauliflower seedling}

The root growth of cauliflower seedling was significantly enhanced by different substrate based $T$. harzianum bio-fungicides as compared to the untreated control. In the $1^{\text {st }}$ year, the root length of cauliflower seedling was ranged from $6.63 \mathrm{~cm}$ to $7.33 \mathrm{~cm}$ among the bio-fungicides treated seedbeds and it was minimum $(5.36 \mathrm{~cm})$ in the untreated control bed (Table 4). Similarly, the root length was varied from $6.53 \mathrm{~cm}$ to $8.07 \mathrm{~cm}$ in the $2^{\text {nd }}$ year and $4.80 \mathrm{~cm}$ to 6.20 $\mathrm{cm}$ in the $3^{\text {rd }}$ year experiment due $T$. harzianum bio-fungicides, while minimum root length of $4.26 \mathrm{~cm}$ and $3.37 \mathrm{~cm}$ were recorded from the control respectively, in $2^{\text {nd }}$ and $3^{\text {rd }}$ trials. Seed treatment with Provax also gave comparatively shorter root length in all the years.

The root weight of individual cauliflower seedling was increased significantly by different substrate based $T$. harzianum bio-fungicides whereas lower root weights were recorded from the Provax and untreated control seedbeds in each year (Table 4). The root weights of individual cauliflower seedling grown in biofungicide treated seedbeds were varied from 0.31 to $0.34 \mathrm{~g}, 0.54$ to $0.64 \mathrm{~g}$ and 0.93 to $1.13 \mathrm{~g}$ during three consecutive years. Root weights of cauliflower seedling were lower in the Provax $(0.33-0.81 \mathrm{~g})$ and untreated control beds $(0.28$ $0.65 \mathrm{~g}$ ) in all the years. The results of three years experiments revealed that both individual as well as mixed substrate based T. harzianum bio-fungicides were almost equally effective in reducing seedling mortality caused by $S$. rolfsii and also enhancing shoot and root growth of cauliflower seedling in seedbed though the substrates, wheat, rice + wheat, rice +grasspea, and wheat + grasspea+ mustard oilcake were superior in these regards.

The results of the present investigation revealed that T. harzianum based biofungicides multiplied on rice bran, wheat bran, grasspea bran and mustard oil cake alone and also in different combinations were equally effective against $S$. rolfsii causing pre-emergence as well as post-emergence mortality of cauliflower seedlings grown in seedbed. The T. harzianum bio-fungicide also enhanced seed germination and vegetative growth of seedlings effectively. Podder et al. (2004) and Rojo et al. (2007) recorded the efficacy of Trichoderma 
spp. as bio-control agents to formulate bio-fungicides after colonization on organic materials. The potentiality of Trichoderma species as bio-control agents for enhancing seed germination and seedling growth in addition to suppression of soil-borne plant pathogenic fungi like Phytophthora, Pythium, Sclerotium, Botrytis, Rhizoctonia and Fusarium of various crops were recorded by many investigators (Benitez et al., 2004; Celar and Valic, 2005; Dubey et al., 2007; Rojo et al., 2007). Significant increase in seedling emergence and suppression of pre-emergence mortality of cabbage seedling were also reported by Prasad and Anes (2008) and Mukhtar (2008). Begum et al. (1999) reported that $T$. harzianum treated seeds of black gram gave $86.7 \%$ to $100 \%$ reduction of foot and root rot disease caused by $S$. rolfsii over the control.

Table 4. Effect of different substrate based T. harzianum bio-fungicides on the root growth of cauliflower seedling in Sclerotium rolfsii inoculated seedbed

\begin{tabular}{l|c|c|c|c|c|c}
\hline \multirow{2}{*}{$\begin{array}{l}\text { Name of substrates based } \\
\text { bio-fungicides }\end{array}$} & \multicolumn{3}{c|}{$\begin{array}{c}\text { Root length of cauliflower } \\
\text { seedling in consecutive three }\end{array}$} & \multicolumn{3}{c}{$\begin{array}{c}\text { Root weight of cauliflower } \\
\text { seedling in consecutive three }\end{array}$} \\
\cline { 2 - 8 } & $1^{\text {st }}$ year & $2^{\text {nd }}$ year & $3^{\text {rd }}$ year & $1^{\text {st } y e a r}$ & $2^{\text {nd }}$ year & $3^{\text {rd }}$ year \\
\hline Rice bran & $7.33 \mathrm{a}$ & $6.70 \mathrm{c}$ & $5.23 \mathrm{bc}$ & $0.31 \mathrm{e}$ & $0.57 \mathrm{ab}$ & $0.97 \mathrm{ab}$ \\
Wheat bran & $7.17 \mathrm{a}$ & $6.87 \mathrm{c}$ & $5.00 \mathrm{~cd}$ & $0.32 \mathrm{~d}$ & $0.59 \mathrm{a}$ & $0.93 \mathrm{~b}$ \\
Grasspea bran & $7.07 \mathrm{a}$ & $6.53 \mathrm{c}$ & $4.80 \mathrm{~cd}$ & $0.34 \mathrm{~b}$ & $0.54 \mathrm{ab}$ & $0.87 \mathrm{~b}$ \\
Rice bran + Wheat bran & $7.00 \mathrm{a}$ & $6.77 \mathrm{c}$ & $5.33 \mathrm{bc}$ & $0.34 \mathrm{~b}$ & $0.64 \mathrm{a}$ & $0.98 \mathrm{ab}$ \\
$\begin{array}{l}\text { Rice bran + Grasspea } \\
\text { bran }\end{array}$ & $6.97 \mathrm{a}$ & $7.00 \mathrm{bc}$ & $6.20 \mathrm{a}$ & $0.34 \mathrm{~b}$ & $0.58 \mathrm{a}$ & $0.98 \mathrm{ab}$ \\
$\begin{array}{l}\text { Rice bran + Mustard } \\
\text { oilcake }\end{array}$ & $7.00 \mathrm{a}$ & $7.87 \mathrm{ab}$ & $5.83 \mathrm{ab}$ & $0.34 \mathrm{~b}$ & $0.57 \mathrm{ab}$ & $0.98 \mathrm{ab}$ \\
$\begin{array}{l}\text { Rice bran+ Wheat bran + } \\
\text { MOC }\end{array}$ & $6.63 \mathrm{a}$ & $8.07 \mathrm{a}$ & $5.73 \mathrm{ab}$ & $0.33 \mathrm{c}$ & $0.60 \mathrm{a}$ & $0.90 \mathrm{~b}$ \\
$\begin{array}{l}\text { Rice bran+ Grasspea bran } \\
+ \text { MOC }\end{array}$ & $6.63 \mathrm{a}$ & $7.47 \mathrm{abc}$ & $5.67 \mathrm{ab}$ & $0.34 \mathrm{~b}$ & $0.56 \mathrm{ab}$ & $0.98 \mathrm{ab}$ \\
$\begin{array}{l}\text { Wheat bran + Grasspea } \\
\text { bran + MOC }\end{array}$ & $6.93 \mathrm{a}$ & $8.03 \mathrm{a}$ & $6.10 \mathrm{a}$ & $0.35 \mathrm{a}$ & $0.55 \mathrm{ab}$ & $1.13 \mathrm{a}$ \\
$\begin{array}{l}\text { Wheat bran + Grasspea } \\
\text { bran+ Rice bran + MOC }\end{array}$ & $7.10 \mathrm{a}$ & $7.88 \mathrm{ab}$ & $5.73 \mathrm{ab}$ & $0.35 \mathrm{a}$ & $0.58 \mathrm{a}$ & $0.93 \mathrm{~b}$ \\
$\begin{array}{l}\text { Seed treatment with } \\
\text { Provax }\end{array}$ & $6.87 \mathrm{a}$ & $5.03 \mathrm{~d}$ & $4.43 \mathrm{~d}$ & $0.33 \mathrm{c}$ & $0.47 \mathrm{~b}$ & $0.81 \mathrm{~b}$ \\
$\begin{array}{l}\text { Control } \\
\text { LSD (P=0.05) }\end{array}$ & $5.36 \mathrm{~b}$ & $4.26 \mathrm{~d}$ & $3.37 \mathrm{e}$ & $0.28 \mathrm{f}$ & $0.36 \mathrm{c}$ & $0.65 \mathrm{c}$ \\
\hline
\end{tabular}

Values in a column with same letter did not differ significantly $(\mathrm{p}=0.05)$ by LSD. 
The promotion of plant growth in terms of length and weight of shoot and root, due to use of Trichoderma spp. as soil amendment was documenetd by several investigators (Chang et al., 1986; Azarmi et al., 2011; Harman et al., 2012; Hermosa et al., 2012; Samolski et al., 2012). Enhancing root growth of cauliflower seedling in $S$. rolfsii sick soils was observed in the present experiment which was supported by the findings of John et al. (2010). Findings of the present investigation i.e. the reduction of post emergence seedling mortality were in agreement with findings of other researchers (Begum et al., 1999; Chowdhury et al., 2000; Hossain and Samsuzzaman, 2003; Yeasmin, 2004; Hossain and Naznin, 2005). The findings of the present investigation revealed that treatment of seedbed soil with $T$. harzianum based bio-fungicides multiplied on rice bran, wheat bran and grasspea bran alone or in combinations might be practiced for controlling seedling mortality caused by $S$. rolfsii and thereby producing healthy seedlings of cauliflower in seedbed.

\section{References}

Anand, S. and J. Reddy. 2009. Biocontrol potential of Trichoderma sp. against plant pathogens, Intern. J. of Agric. Sci. 1(2): 30-39.

Azarmi, R., B. Hajieghrari and A. Giglou. 2011. Effect of Trichoderma isolates on tomato seedling growth response and nutrient uptake. African J. of Biotech. 10(31): $5850-5855$.

BBS. 2013. Year Book of Agricultural statistics of Bangladesh. Ministry of Planning, Government of the People's Republic of Bangladesh, Dhaka.

Begum, M. M., M. A. Rahman and I. Hossain. 1999. Antagonistic effect of Trichoderma harzianum on Sclerotium rolfsii in food legumes. Bangladesh J. Bio. Sci. 7: 81-88.

Benítez, T., A. M. Rincón, M. C. Limón and A. C. Codón. 2004. Biocontrol mechanisms of Trichoderma strains. Int. Microbio. 7:249-260.

Brown, E. A. and F. F. Hendrix. 1980. Distribution and control of S. rolfsii on apple. Plant Dis. 64:205-206.

Celar, F. and N. Valic. 2005. Effects of Trichoderma spp and Glicladium roseum culture filtrates on seed germination of vegetables and maize. J. of Plant Dis. Protec. 112(4): 343-350.

Chang, Y. C., Y. C.Chang, R. Baker, O. Kleifeld and I. Chet. 1986. Increased growth of plants in the presence of the biological control agent Trichoderma harzianum. Plant Dis. 70: $145-148$.

Chowdhury, M. S. M., I. Hossain, G. A. Fakir, F. M. Aminuzzaman and M. R. Islam. 2000. Tolerance of Trichoderma harzianum and Gliocladium viride agrochemical and their antagonistic effect on seed borne mycoflora of pigeon pea. Bangladesh J. of Seed Sci. Tech. 4(1\&2):83-86.

Das, B. C., S. K. Roy and L. C. Bora. 1997. Mass multiplication of Trichoderma species on different media. J. Agril. Sci. Soc. of North East India. 10(1): 95-100. 
Dubey, S. C., M.Suresha and B. Singha. 2007. Evaluation of Trichoderma species against Fusarium oxysporum f. sp. ciceris for integrated management of chickpea wilt. Biological Control. 40: 118-127.

FAOSTAT. 2012. Food and Agriculture Organization of United Nations statistical database. http://faostat.fao.org/.

Faruk M. I.,M. L. Rahman, M. M. H. Mustafa, M. M. Rahman and M. A. Rahman. 2014. Screening of carrier materials to formulate Trichoderma harzianum based biofungicide against foot and root rot disease of Tomato (Lycopersicon esculentum L.). Bangladesh J. Agril. Res. 39(2): 197-209.

Harman G E., A. G. Taylor and D. Hornby. 1991. Development of an effective biological seed treatment system. Biological control of soil-borne Plant Pathogens. Pp 415-426.

Harman, G. E., A. H. Herrera-Estrella, B. A. Horwitz and M. Lorito. 2012. Special issue: Trichoderma - from basic biology to biotechnology. Microbiology 158: 1-2

Harman, G. E., C. R. Howell, A. Viterbo, I.Chet and M. Lorito. 2004. Trichoderma species-opportunistic, avirulent plant symbionts. Nature Reviews. 2:43-56.

Hermosa, R., A. Viterbo, I. Chet and E. Monte. 2012. Plant-beneficial effects of Trichoderma and of its genes. Microbiology 158: 17-25

Hossain, I. and M. H. A. Naznin. 2005. BAUBiofungicide in controlling seedling diseases of summer vegetables. BAU Research Progress, 15:35.

Hossain, I. and Shamsuzzaman. 2003. Developing Trichoderma based biofungicide using agro-wastes. BAU Research Progress, 14: 149-50.

John, R. P., R. D. Tyagi, D. S. Prévost, K. Brar, S. Pouleur and R. Y. Surampalli. 2010. Mycoparasitic Trichoderma viride as a biocontrol agent against Fusarium oxysporum f. sp. adzuki and Pythium arrhenomanes and as a growth promoter of soybean. Crop Protection 29(12):452-1459.

Kirsh, V.A., U. Peters, S.T. Mayne, A.F. Subar, N. Chatterjee, C.C. Johnson and R. B. Hayes. 2007. Prospective study of fruit and vegetable intake and risk of prostate cancer. J. Natl. Cancer Inst. 99: 1200-1209.

Kulkarni, M., R. Chaudhari and A. Chaudhari. 2007. Novel tensio-active microbial compounds for biocontrol applicatins. In: General Concepts in Integrated Pest and Disease Management (eds. A. Ciancio and K.G. Mukerji). Springer: 295-304.

Mondal, S.N., K. Kageyama and M. Hyakumachi. 1996. Decrease germination and virulence of oospore of Pythium aphanidermato in relation to loss of endogenous carbon during incubation on soil. Soil. Biol. Biochem. 28:545-553.

Morsy, E. M., K. A. Abdel-Kawi and M. N. A. Khalil. 2009. Efficacy of Trichoderma viride and Bacillus subtilis as biocontrol agents against Fusarium solani on tomato plants. Egyptian J. of Plant Pathol. 37(1): 47-57.

Mukhtar, I. 2008. Influence of Trichoderma species on seed germination in okra. Mycopathol. 6(1\&2): 47-50.

Najar, A. G., A. Anwar, L. Masoodi and M. S. Khar. 2011. Evaluation of native biocontrol agents against Fusarium solani f. sp. melongenae causing wilt disease of brinjal in Kashmir. J. Phytology. 3: 31-34. 
Naseby, D.C., J.A. Pascual and J.M. Lynch. 2000. Effect of biocontrol strains of Trichoderma on plant growth, Pythium ultimum populations, soil microbial communities and soil enzyme activities. J. App. Microbiol. 88: 161-169.

Poddar, R. K., D. V. Singh and S. C. Dubey. 2004. Integrated application of Trichoderma harzianum mutants and carbendazim to manage chickpea wilt (Fusarium oxysporum f.sp. ciceri). Indian J. Agric. Sci. 74: 346-348.

Prasad, D. and K. M. Anes. 2008. Effect of metabolites of Trichoderma harzianum and T. viride on plant growth and Meloidogyne incognita on okra. Annual Plant Protec. Sci. 16:461-465.

Punja, Z. K., R. G. Grogan and T. Unruh. 1982. Comparative control of S. rolfsii on golf grass in Northern Calfornia with fungicides, inorganic salt and Trichoderma spp. Plant Dis. 66: 1125-1128.

Rojo, F.G., M. M. Reynoso, M. F. Sofia, N. Chulze1 and A.M. Torres. 2007. Biological control by Trichoderma species of Fusarium solani causing peanut brown root rot under field conditions. Crop Protection 26: 549-555.

Rettinassabababy, C. and N. Ramadoss. 2000. Effect of different substrates on the growth and sporulation of Trichoderma viride native isolates. Agril. Sci. Digest. 20(3): 150152.

Roy, S. J., B. S. Das and L. C. Bora. 1989. Non pestcidal management of damping-off of cabbage caused by Rhizoctonia solani Kuehn. J. Agril. Sci. Society of North East India. 11(2):127-130.

Sabalpara A. N., J. Priya, R. R. Waghunde and J. P.Pandya. 2009. Antagonism of Trichoderma against sugarcane wilt pathogen (Fusarium moniliformae), AmericanEurasian J. Agric. Environ. Sci. 3(4): 637-638.

Samolski, I., A. M. Rincon, L. M. Pinzon, A. Viterbo and E. Monte. 2012. The qid74 gene from Trichoderma harzianum has a role in root architecture and plant biofertilization. Microbiology 158: 129-138.

Shamarao, J., A. L. Siddaramaidah, H. Narayanaswamy and S. Jahagirdar. 1998. Screening of substrates of mass multiplication of Trichoderma viride. Karnataka J. Agril. Sci. 11(1): 233-236.

Shamsuzzaman, S. M. A. Islam and I. Hossain. 2003. Trichoderma culture and germination of sweet gourd seed. Bangladesh J. Seed Sci. Tech. 7(1 \& 2): 91-95.

Strange, R. N. and R. R. Scott. 2005. Plant disease: a threat to global food security. Annu. Rev. Phytopathol. 43:83-116.

Vey, A., R. E. Hoagland and T. M. Butt. 2001. Toxic metabolites of fungal biocontrol agents. In: Butt TM, Jackson C, Magan N (eds) Fungi as biocontrol agents: Progress, problems and potential. CAB International, Bristol. Pp 311-346.

Yeasmin, R. 2004. Integrated management of seedling diseases of blackgram, mungbean and lentil. M. S. thesis. Department Plant Pathology, Bangladesh Agricultural University, Mymenshing, Bangladesh. 72-73 Pp. 